\title{
Morphometric differentiation in four populations of signal crayfish, Pacifastacus leniusculus (Dana), in Poland
}

\author{
Łucjan Chybowski
}

Received - 02 June 2014/Accepted - 31 July 2014. Published online: 30 September 2014; @Inland Fisheries Institute in Olsztyn, Poland Citation: Chybowski Ł. 2014 - Morphometric differentiation in four populations of signal crayfish, Pacifastacus leniusculus (Dana), in Poland Arch. Pol. Fish. 22: 229-233.

\begin{abstract}
The subject of the study was four populations of signal crayfish from Naryjska Struga River and lakes Pobłędzie, Mauda, and Staw Płociczno. The morphometric differentiation of female and male signal crayfish was studied with discriminant analysis. It was confirmed that both females and males from the Naryjska Struga River differ from the crayfish from the three lakes. The characters that best discriminated females were those associated with the cephalothorax and cheliped width, while in males they were those associated with the chelipeds and the abdomen.
\end{abstract}

Keywords: signal crayfish, morphological characters, discriminant analysis, alien species

The history of the signal crayfish, Pacifastacus leniusculus (Dana), in Poland dates from the 1972, when the signal crayfish was first imported (Kossakowski et al. 1978, 1983, Gondko and Girsztowtt 1987), and next in 1990-1991 (Krzywosz 1994). Studies of crayfish morphology are few because they are labor intensive and time consuming. In Poland, Kossakowski (1962) and Podsiadło and Olech (1994) have studied the morphometric characters of the noble crayfish, Kossakowski (1962) and Andrzejewski et al. (2001) have studied those of the narrow-clawed crayfish, and Kossakowski (1962)

Ł. Chybowski [ڤ"]

Inland Fisheries Institute in Olsztyn, Poland

Department of Lake Fisheries in Giżycko

ul. Rajska 2, 11-500 Giżycko, e-mail: lchybowski@infish.com.pl and Chybowski (2007) those of the spiny-cheek crayfish, Orconectes limosus (Raf.), but no studies to date have been done in Poland of the signal crayfish, $P$. leniusculus, which is occurring in an increasing number of locations (Jażdżewski and Konopacka 1993, 1995). The aim of the study was to examine morphological differentiation among four populations of signal crayfish. Discriminant analysis was used since it permits examining the differences among several groups and analyzing more variables simultaneously.

The subject of the study was the signal crayfish originating from the Naryjska Struga River and lakes Pobłędzie, Mauda, and Staw Płociczno. The Naryjska Struga River is located in northern Poland, and it is a sub-montane stream (Krzywosz 2006). The mean width of the river is approximately $5 \mathrm{~m}$. The river bottom is hard with gravel and rocks. The stream gradient is 3.6\%o. The river links lakes Narie and Mildzie (Krzywosz 2006). Lakes Pobłędzie, Mauda, and Staw Płociczno are in northeast Poland. The surface area of Lake Pobłędzie is 57.6 ha, maximum depth is $15.4 \mathrm{~m}$, and mean depth is $5.9 \mathrm{~m}$. The surface area of Lake Mauda is 37.9 ha, maximum depth is $17.5 \mathrm{~m}$, and mean depth is $5.9 \mathrm{~m}$. The surface area of Lake Staw Płociczno is 22.1 ha, maximum depth is $14.2 \mathrm{~m}$, and mean depth is $3.0 \mathrm{~m}$. In the summer, distinct thermal stratification forms in the lakes. The lakes are eutrophic, and their fisheries classification is as bream 


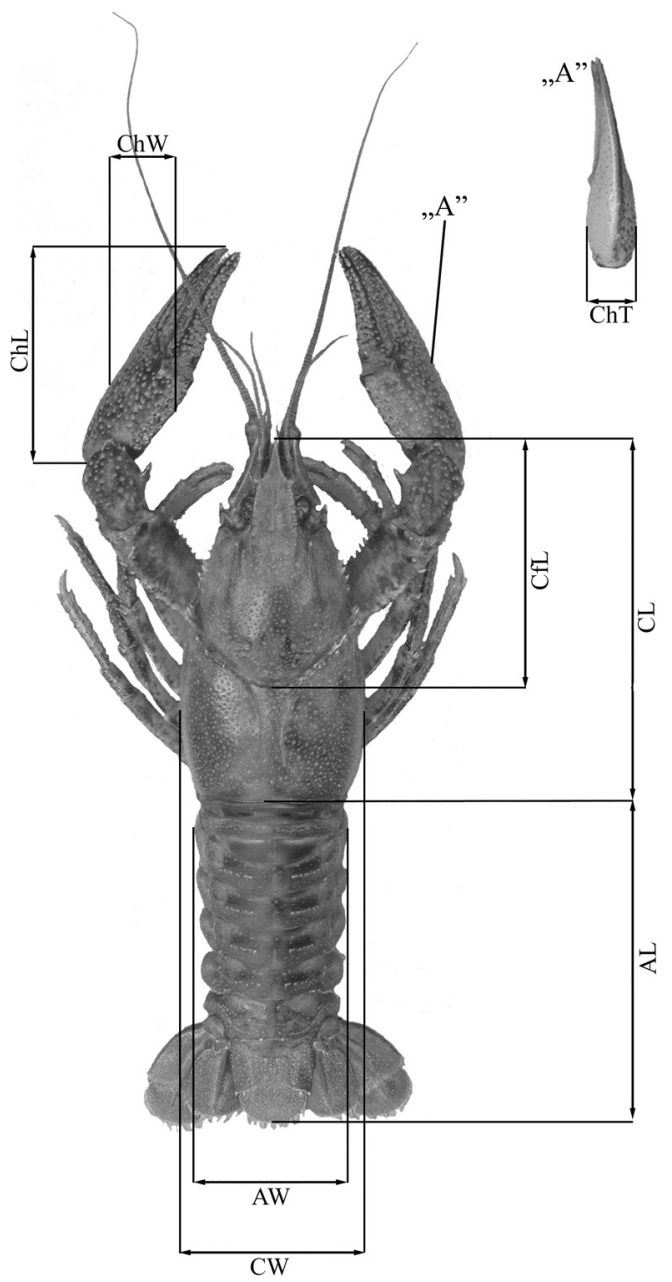

Figure 1. Measurements of the studied signal crayfish ( $P$. leniusculus). CL - cephalothorax length, $\mathrm{AL}$ - abdomen length, $\mathrm{CfL}$ - cephalothorax length to the cervical groove, $\mathrm{ChL}$ - cheliped length, CW - greatest cephalothorax width, AW - abdomen width, ChW - greatest cheliped width, ChT - greatest cheliped thickness. lakes. The study material was collected in 2013. Evo traps were used to catch the crayfish, and 167 signal crayfish specimens were caught, of which 89 were female and 78 male. The crayfish were measured, weighed, and their sex was determined. Eight measurements of morphological characters were recorded (Fig. 1; Kossakowski 1962) to the nearest $0.1 \mathrm{~mm}$.

The total body length (TL) of female signal crayfish ranged from 73.0 to $145.0 \mathrm{~mm}$, and for males it was from 66.0 to $144.0 \mathrm{~mm}$ (Table 1). Body weight (W) was, accordingly, from 12.0 to $92.2 \mathrm{~g}$ and from 7.6 to $96.2 \mathrm{~g}$ (Table 1). The mean total body lengths and body weights of the females and males from Naryjska River were lower (Fisher's test, $\mathrm{P} \leq 0.05$ ) than those of the males and females from the lake (Table 1). Morphological differentiation of the populations examined was evaluated by analyzing all of the variables simultaneously with discriminant analysis. Forward stepwise discriminant analysis was applied. The analysis was performed separately for males and females using the discriminant analysis module in Statistica v.8.08. The raw discriminant function coefficients presented in Tables 2 and 3 served to calculate the value of the discrimination function, while the standardized coefficients spoke to the input of the variables to the various functions.

The results of the discriminant analysis permitted designating the six characters that best discriminated the populations examined. Three discriminant functions each were created for females and males. In both instances, only the first two functions were

Table 1

General characteristics of the female and male examined from four populations of signal crayfish, P. leniusculus, in Poland. $\mathrm{n}-$ number (individuals), TL - total body length (mm), W - body weight $(\mathrm{g}), \pm-95 \%$ confidence interval for means. Values with the same letter index in columns do not differ significantly statistically (Fisher's test, $\mathrm{P} \leq 0.05$ )

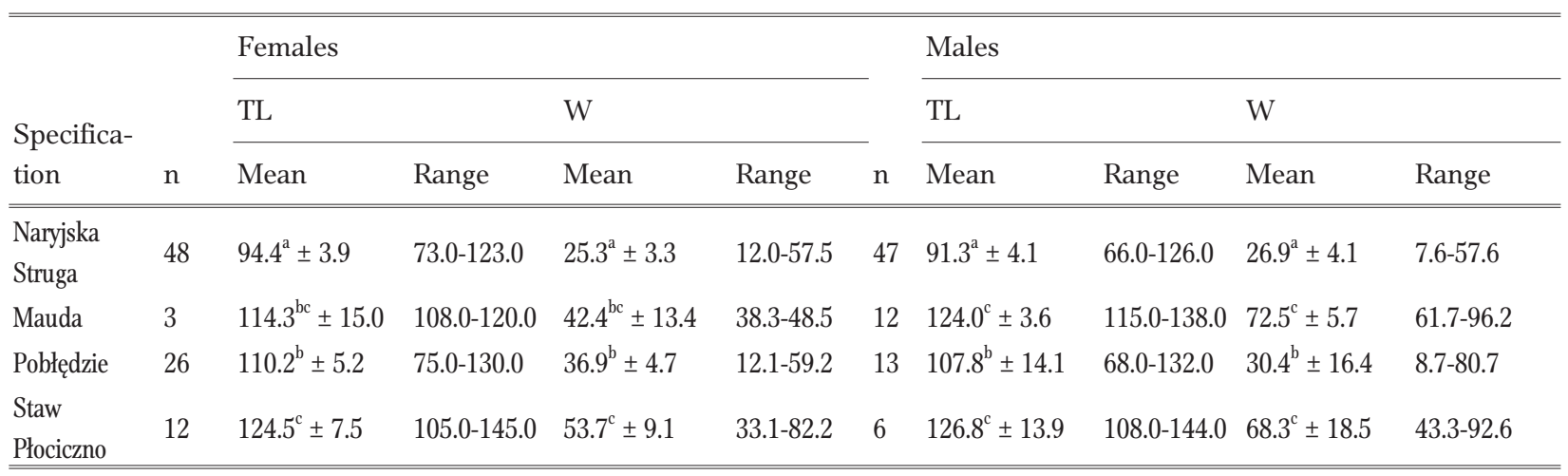


Table 2

Coefficients of discriminant functions for females from four populations of signal crayfish, P. leniusculus, in Poland. Abbreviations as in Fig. 1

\begin{tabular}{lllll}
\hline \hline & \multicolumn{2}{l}{ Function 1 } & \multicolumn{2}{l}{ Function 2 } \\
\cline { 2 - 5 } Parameters & Raw & Standardized & Raw & Standardized \\
\hline \hline Constant & 5.62 & & 5.77 & \\
CfL & -0.69 & -3.18 & 0.80 & 3.65 \\
CL & 0.34 & 2.26 & -1.08 & -7.16 \\
CW & 0.15 & 0.57 & 0.50 & 1.94 \\
ChL & -0.19 & -1.14 & 0.26 & 1.55 \\
ChW & 0.98 & 2.68 & -0.11 & -0.29 \\
ChT & -1.35 & -1.87 & -0.01 & -0.01 \\
Percentage & & & & \\
of explained & 80.85 & & 17.24 & \\
variance & & & & \\
\hline \hline
\end{tabular}

Table 4

Mean values of discriminant variables for four populations of signal crayfish, $P$. leniusculus, in Poland

\begin{tabular}{|c|c|c|c|c|}
\hline \multirow[b]{3}{*}{ Specification } & \multicolumn{4}{|c|}{ Mean canonical variables } \\
\hline & \multicolumn{2}{|l|}{ Females } & \multicolumn{2}{|l|}{ Males } \\
\hline & Function 1 & Function 2 & Function 1 & Function 2 \\
\hline $\begin{array}{l}\text { Naryjska } \\
\text { Struga }\end{array}$ & 1.31 & -0.05 & -1.31 & 0.02 \\
\hline Mauda & -1.44 & 1.52 & 1.96 & -1.20 \\
\hline Pobłędzie & -1.42 & 0.56 & 1.62 & 0.49 \\
\hline Staw Płociczno & -1.82 & -1.39 & 2.83 & 1.15 \\
\hline
\end{tabular}

statistically significant, and only they were included in further analysis. Among the females, the characters that best discriminated the populations examined were: cephalothorax length to the cervical groove (CfL); cephalothorax length (CL); greatest cephalothorax width (CW); cheliped length (ChL); greatest cheliped width (ChW); greatest cheliped thickness (ChT) (Table 2). In males these characters were: cephalothorax length (CL); abdomen length (AL); greatest cephalothorax width (CW); cephalothorax length to the cervical groove (CfL);
Table 3

Coefficients of discriminant functions for males from four populations of signal crayfish, $P$. leniusculus, in Poland. Abbreviations as in Fig. 1

\begin{tabular}{lllll}
\hline \hline & \multicolumn{2}{l}{ Function 1} & \multicolumn{2}{l}{ Function 2} \\
\cline { 2 - 5 } Parameters & Raw & Standardized & Raw & Standardized \\
\hline \hline Constant & -4.05 & & -2.24 & \\
CL & 0.21 & 1.54 & 0.57 & 4.13 \\
AL. & -0.25 & -2.03 & 0.03 & 0.24 \\
CW & 0.02 & 0.10 & -0.91 & -3.95 \\
CfL & 0.20 & 1.04 & -0.05 & -0.24 \\
ChT & 0.91 & 2.47 & 0.52 & 1.40 \\
ChW & -0.49 & -2.39 & -0.40 & -1.97 \\
$\begin{array}{l}\text { Percentage } \\
\text { of explained }\end{array}$ & 85.77 & & 11.61 & \\
variance & & & & \\
\hline \hline
\end{tabular}

greatest cheliped thickness (ChT); greatest cheliped width (ChW) (Table 3). The first discriminant function in females was responsible for $80.85 \%$ of the variation explained, or $80.85 \%$ of the discriminatory power is explained by this function. The characters that had the greatest impact on morphological differentiation in the populations examined were CfL, $\mathrm{ChW}$, and CL. The second discriminant function only explained $17.24 \%$ of the variation. The characters that had the greatest impact on morphological differentiation were CL and CfL (Table 2). In males, the first discriminant function was responsible for $85.77 \%$ of the variation explained. The characters that had the greatest impact on morphological differentiation were ChT, ChW, and AL. The second discriminant function only explained $11.61 \%$ of the variation. The characters that had the greatest impact were CL and CW (Table 3).

The mean values of the discriminant functions presented in Table 4 led to the conclusion that in the cases of both females and males, the first discriminant function distinctly distinguishes the crayfish from Naryjska Struga Lake from the other crayfish (the mean discriminant values for the crayfish from the Naryjska Struga River are clearly divergent from the remaining means; Table 4). This 


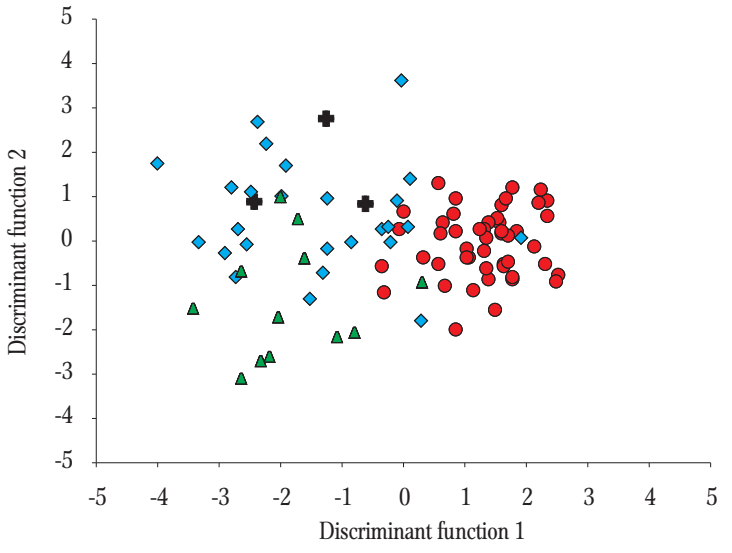

(a)

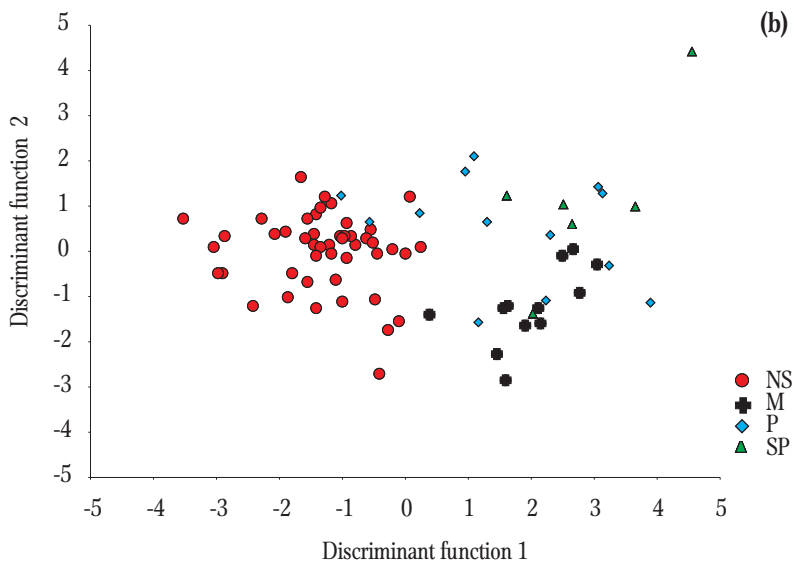

Figure 2. Discrimination of the different population of signal crayfish (P. leniusculus) by the first two discriminant functions for females (a) and males (b). NS - Naryjska Struga, M - Mauda, P Pobłędzie, SP - Staw Płociczno.

hypothesis is confirmed by the graphic presentations of the results (Fig. 2). Females and males from the Naryjska Struga River form clearly distinct groupings on the right and left figures, respectively. The means of the second function in females do not identify any groups, while the second function of the males distinguished the crayfish from Lake Mauda (Table 4). It should be borne in mind, however, that this function has weak discriminatory power and only explains a small percentage of the variance.

Table 5 presents the classification accuracy matrix for female and male signal crayfish for the different populations. Only the crayfish from Naryjska Struga were classified with unequivocal accuracy. The classification of the crayfish from the other populations was not as accurate. The characters that best discriminated the females were those associated with the cephalothorax and cheliped width (cephalothorax length to the cervical groove (CfL), cephalothorax length (CL), and greatest cephalothorax width (ChW)), while in males they were characters associated with the cheliped and abdomen (greatest cheliped thickness (ChT), greatest cheliped width (ChW), and abdomen length AL)). Simultaneously, distinct morphometric differentiation was noted between the crayfish from the river and the lakes. Chybowski (2007), in a study of the morphometric characters of the spiny-cheek crayfish, reports that the females of the species that were the same total body length, had longer abdomens (AL), shorter cephalothorax length (CL), a shorter anterior section of the cephalothorax (CfL), and shorter cheliped length (ChL) than did males. The chelipeds of the females were narrower (ChW) that those of the males. These same characters distinguished the signal crayfish examined, and the discriminant analysis permitted separating the characters distinguishing males and females.

Table 5

Classification accuracy matrix for female and male signal crayfish of different populations of signal crayfish, $P$. leniusculus, in Poland. Data are number of individuals/\% classified to a given population

\begin{tabular}{|c|c|c|c|c|c|c|c|c|}
\hline \multirow[b]{2}{*}{ Specification } & \multicolumn{4}{|l|}{ Females } & \multicolumn{4}{|l|}{ Males } \\
\hline & $\begin{array}{l}\text { Naryjska } \\
\text { Struga }\end{array}$ & Mauda & Pobłędzie & $\begin{array}{l}\text { Staw } \\
\text { Płociczno }\end{array}$ & $\begin{array}{l}\text { Naryjska } \\
\text { Struga }\end{array}$ & Mauda & Pobłędzie & $\begin{array}{l}\text { Staw } \\
\text { Płociczno }\end{array}$ \\
\hline $\begin{array}{l}\text { Naryjska } \\
\text { Struga }\end{array}$ & $48 / 100.0$ & $0 / 0.0$ & $0 / 0.0$ & $0 / 0.0$ & $47 / 100.0$ & $0 / 0.0$ & $0 / 0.0$ & $0 / 0.0$ \\
\hline Mauda & $0 / 0.0$ & $1 / 33.3$ & $2 / 66.7$ & $0 / 0.0$ & $1 / 8.3$ & $8 / 66.7$ & 2/16.7 & $1 / 8.3$ \\
\hline Pobłędzie & $7 / 26.9$ & $1 / 3.8$ & $16 / 61.5$ & $2 / 7.8$ & $3 / 23.1$ & $4 / 30.7$ & $3 / 23.1$ & $3 / 23.1$ \\
\hline Staw Płociczno & $1 / 8.3$ & $0 / 0.0$ & $3 / 25.0$ & $8 / 66.7$ & $0 / 0.0$ & $1 / 16.7$ & $2 / 33.3$ & $3 / 50.0$ \\
\hline
\end{tabular}


Haddaway et al. (2012) studied populations of Austropotamobius pallipes (Lereboullet) from lentic and lotic waters, and report that crayfish from lotic waters had longer, wider chelipeds than crayfish from lentic waters. Additionally, crayfish from lentic waters were relatively wider. Grandjean and Souty-Grosset (2000) report that female and male $A$. pallipes from ponds and streams in France were best discriminated by abdomen width and cheliped width, while Sint et al. (2005) report that the characters that best discriminated Astacus astacus L. and A. pallipes from different populations were those associated with the cephalothorax. The aim of the study was to examine the morphological differences of four populations of signal crayfish, and it was not planned to examine the differences between populations from lentic and lotic waters. Nevertheless, the results indicate that such differentiation exists. It would be advisable to collect more abundant study material and to conduct more detailed studies.

\section{References}

Andrzejewski W., Czarnecki M., Mastyński J. 2001 Morphometric features of crayfish (Astacus leptodactylus Esch.) coming from the Gaj Lake - Ann. Poznań Agricult. Univ. - Anim. Sci. 3: 47-55.

Chybowski Ł. 2007 - Morphometrics, fecundity, density, and feeding intensity of the spinycheek crayfish Orconectes limosus (Raf.) in natural conditions - Arch. Pol. Fish. 15: $175-241$.
Gondko R., Girsztowtt Z. 1987 - A new species of crayfish, Pacifastacus leniusculus Dana, inhabits Polish waters Kieleckie Studia Biologiczne 4: 133-143. (in Polish).

Grandjean F., Souty-Grosset C. 2000 - Genetic and morphological variation in the endangered crayfish species, Austropotamobius pallipes (Lereboullet) (Crustacea, Astacidae) from the Poitou-Charentes region (France) Aquatic Sciences, 62, 1-19.

Haddaway N. R., Mortimer R. J. G., Christmas M., Grahame J. W., Dunn A. M. 2012 - Morphological diversity and phenotypic plasticity in the threatened British white-clawed crayfish (Austropotamobius pallipes) Aquatic Conserv: Mar. Freshw. Ecosyst. 22: 220-231.

Jażdżewski K., Konopacka A. 1993 - Survey and distribution of Crustacea Malacostraca in Poland - Crustaceana 65: 176-191.

Jażdżewski K., Konopacka A. 1995 - Catalog of Polish Fauna, XIII, Malcostraca - Muzeum Instytutu Zoologii PAN, Warszawa: 84-96. (in Polish).

Kossakowski J. 1962 - A comparison of several morphometric indices of three crayfish species of Polish waters - Rocz. Nauk Rol. 81-B-2: 359-376 (in Polish).

Kossakowski J., Mnich M., Kossakowski G. 1978 - The first introduction of the crayfish Pacifastacus leniusculus Dana into Polish waters - Freshwater Crayfish 4: 195.

Kossakowski J., Mnich M., Kossakowski G. 1983 - An attempt to raise juvenile crayfish Pacifastacus leniusculus Dana - Freshwater Crayfish 5: 555-556.

Krzywosz T. 1994 - Introduction of the signal crayfish, Pacifastacus leniusculus Dana, to Polish waters - Rocz. Nauk. PZW 7: 81-93 (in Polish).

Podsiadło E., Olech W. 1994 - Variability of some body proportions in noble crayfish - Astacus astacus (L.) depending on the size of individuals and their sex - Ann. Warsaw Agricult. Univ. Anim. Sci. 30: 3-14.

Sint D., Dalla Via J., Füreder L. 2005 - Morphological variations in Astacus astacus L. and Austropotamobius pallipes (Lereboullet) populations - Bull. Fr. Péche. Piscic. 376-377: 637-652. 